Рожков А. О., кандидат сільськогосподарських наук

Харківський національний аграрний університет ім. В. В. Докучаєва

\title{
УРОЖАЙНІСТЬ ЗЕРНА ТРИТИКАЛЕ ЯРОГО ТА БІОЕНЕРІЕТИЧНА ЕФЕКТИВНІСТЬ ЙОГО ВИРОЩУВАННЯ ЗАЛЕЖНО ВІД ЗАСТОСУВАННЯ РІЗНИХ СПОСОБІВ СІВБИ Й НОРМ ВИСІВУ
}

\author{
Рецензент - доктор сільськогосподарських наук, професор Т. І. Гопцій
}

\begin{abstract}
Висвітлено результати трирічних досліджень щчодо впливу ценотичних факторів: способів сівби та норм висіву на зернову продуктивність рослин тритикале ярого. У дослідах встановлено перевагу смугового способу сівби на підвищення показників економічної та біоенергетичної ефективності вирощування тритикале ярого. За смугового способу сівби вища врожайність $і$ більи високі показники економічної та біоенертетичної ефективності виромування посівів тритикале ярого відзначені за норми висіву 550 нас. $/ \mathrm{M}^{2}$, тоді як за рядкового способу - за норми

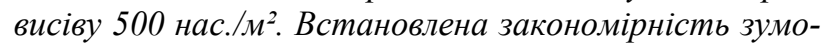
влена послабленням иенотичної напруги за смугового способу сівби, щзо створюе умови для повночінного розвитку більшої кількості рослин на одиниці площчі nocisy.
\end{abstract}

Ключові слова: иенотична напруга, норма висіву, спосіб сівби, тритикале яре, урожсайність, економічна та біоенертетична ефективність.

Постановка проблеми. Протягом останнього періоду як у світовій практиці сільського господарства, так і в нашій країні спостерігається тенденція до зниження затрат на вирощування сільськогосподарських культур. У зв'язку 3 цим виникає необхідність удосконалення елементів технології їх вирощування 3 метою підвищення врожайності за одночасного зниження витрат на одержання одиниці продукції.

Аналіз останніх досліджень i публікацій, у яких започатковано розв'язання проблеми. Чисельними дослідженнями доведено, що оптимальна густота стояння рослин $є$ основним фактором у підвищенні рівня їх продуктивності [10, 11]. Сдиної думки стосовно того, за якої густоти стояння рослин можна одержати максимальний врожай, не існує й досі. Для з'ясування проблеми необхідно розуміти процес формування врожаю у його динаміці 3 урахуванням розвитку елементів урожайності. Всі ці процеси протікають по-різному залежно від комплексного впливу ендогенних та екзогенних факторів. Тому стосовно норми висіву не може бути розроблено стандарту, - вони мають встановлюватися з ура- хуванням погодних умов, сортоособливостей $\mathrm{i}$ технології вирощування.

Підвищення рівня врожайності та покращання якості продукції завжди супроводжується додатковими затратами коштів. Саме тому користь від їх застосування залежить не стільки від приросту врожайності, скільки від економічної ефективності, яка $\epsilon$ важливим показником оцінки доцільності впровадження у виробництво досліджуваних елементів технології вирощування, що забезпечують приріст урожайності $[8,9]$.

Останнім часом поряд з економічною оцінкою все більшої уваги дослідників привертає біоенергетична оцінка ефективності технологій вирощування, окремих агрозаходів і т. п. [12]. Виявлення енергоощадних варіантів (сортів, технологій, агрозаходів) пов'язано з оцінкою співвідношення кількості енергії, накопиченої рослинами, із затратами антропогенної енергії [6]. Нині така оцінка $є$ універсальною й дає змогу порівнювати енергоємність будь-якого агрозаходу в різних умовах [2, 3, 5-7].

Інтенсифікація сільськогосподарського виробництва та підвищення врожайності супроводжується збільшенням витрат не поновлюваної енерriї, в тому числі й за рахунок удосконалення технології вирощування культури. Це стосується й розробки енергоощадних технологій вирощування, за яких буде менше витрачатися енергії.

Мета і завдання досліджень. Метою проведених досліджень було визначення впливу різних варіантів ценотичної напруги на врожайність зерна, економічну й біоенергетичну ефективність вирощування рослин тритикале ярого.

Завдання досліджень: визначити ефективність норм висіву, способів сівби та їх впливу на формування зернової продуктивності посівів тритикале ярого, встановити економічну й біоенергетичну ефективність досліджуваних елементів технології.

Методика досліджень. Даний дослід проведено протягом 2008-2010 pp. за загальнопоширеною методикою [4]. Об'єктом досліджень ви- 


\section{СІЛЬСЬКЕ ГОСПОДАРСТВО. РОСЛИННИЦТВО}

ступали рослини тритикале ярого сорту Коровай харківський, предметом досліджень - способи сівби та норми висіву.

Сівбу тритикале ярого проводили рядковим та смуговим способом нормами висіву від 400 до

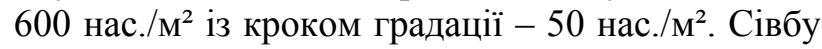
рядковим способом проводили сівалкою С3-3,6, смуговим - сівалкою прямої сівби АПП-6 ВАТ «Фрегат». За смугового способу насіння висівалося у межах смуги 15 см завширшки за ширини між центрами смуг 30 сантиметрів. Різниця між способами сівби пояснюється конструктивними особливостями сівалок. Сівалка С3-3,6 забезпечує висів насіння дисковим сошником, у сівалки АПП-6 висіваючим органом є культиваторна лапа, робоча ширина якої - 40 сантиметрів.

Результати досліджень. Характерною біологічною особливістю ярих зернових хлібів, у тому числі тритикале, є низька здатність формування бічних пагонів. У зв'язку з цим особливого значення набуває питання оптимізації густоти посівів та характеру їх розподілу за площею живлення.

У досліді з вивчення впливу ценотичних факторів - способів сівби та норм висіву - на врожайність зерна тритикале ярого визначено досить сильну реакцію рослин на застосування різних варіантів ценотичної напруги між рослинами у посівах (табл. 1). Залежно від застосування різних градацій норми висіву діапазон зміни врожайності рослин тритикале ярого перевищував $25 \%$ (від 2,64 т/га за норми висіву -400 нас. $/ \mathrm{m}^{2}$ до 3,32 т/га за норми висіву -600 нас./ ${ }^{2}$ ).

За показниками врожайності зерна залежно від впливу різних норм висіву, у середньому за три роки досліджень, виділено дві гомогенні групи (див. рис.). Урожайність істотно підвищувалася зі збільшенням норми висіву - 3400 до 500 нас./м². Разом із тим слід відзначити встановлену закономірність зменшення ефекту за по- ступового збільшення норми висіву. Так, зі збільшенням норми висіву 3400 до 450 нас. $/ \mathrm{M}^{2}$ урожайність зерна збільшувалася на 0,25 т/га при подальшому іiі збільшенніна сталу величину - 50 нас./ ${ }^{2}$, урожайність, відповідно, зростала на 0,23 та на 0,17 т/га. Зі збільшенням норми висіву 3550 до 600 нас./ ${ }^{2}$ приріст врожайності взагалі становив лише 0,03 тонн/гектар.

У проведеному досліді ефект застосування норми висіву суттєво залежав від способу сівби. Урожайність зерна рослин тритикале ярого залежно від застосування різних норм висіву на варіантах рядкового способу сівби варіювала у межах від 2,59 до 3,01 т/га (розбіжність - 0,42 т/га, або 16,2 \%), смугового - від 2,69 до 3,63 т/га (розбіжність - 0,94 т/га, або 34,9\%). Відповідно до одержаних результатів, оптимальною нормою висіву за рядкового та смугового способів сівби була - 500 та 550 нас./м² відповідно.

Ефективність застосування різних норм висіву на смугових посівах принципово відрізнялася від ефекту норми висіву, одержаного на рядкових посівах. Найвищої зернової продуктивності на варіантах смугового способу сівби (3,56 т/га) досягнуто за норми висіву 550 нас./ $\mathrm{m}^{2}$. Із підвищенням норми висіву 3550 до 600 нас./ ${ }^{2}$ була відзначена лише тенденція до збільшення врожайності.

Найменшу ефективність застосування смугового способу сівби відзначено за норми висіву 400 нас./м². Так, приріст урожайності в разі застосування смугового способу сівби, порівняно 3 рядковим за норми висіву - 400 нас./ м $^{2}$ становила $-0,10$ т/га за HIP $_{05}$ часткових порівнянь ефекту - 0,30 т/га. Більше ефективність смугового способу сівби проявлялася за норм висіву 550 та 600 нас./м². Приріст врожайності в разі застосування смугового способу за цих норм висіву становила 0,55 та 0,62 т/га відповідно.

\section{1. Урожсайність рослин тритикале ярого залежно від впливу способів сівби та норм висіву, т/га (середнє за 2008-2010 рр.)}

\begin{tabular}{|c|c|c|c|}
\hline \multirow{2}{*}{$\begin{array}{c}\text { Чинник А - норма висіву, } \\
\text { нас./ }{ }^{2}\end{array}$} & \multicolumn{2}{|c|}{ Чинник В - спосіб сівби } & \multirow{2}{*}{ Середнє } \\
\hline & рядковий & смуговий & \\
\hline 400 & 2,59 & 2,69 & 2,64 \\
\hline 450 & 2,78 & 3,00 & 2,89 \\
\hline 500 & 2,95 & 3,29 & 3,12 \\
\hline 550 & 3,01 & 3,56 & 3,29 \\
\hline 600 & 3,01 & 3,63 & 3,32 \\
\hline Середнє & 2,87 & 3,23 & 3,05 \\
\hline \multicolumn{4}{|c|}{$\mathrm{HIP}_{05}$ головного ефекту норми висіву $-0,27$} \\
\hline \multicolumn{4}{|c|}{$\mathrm{HIP}_{05}$ головного ефекту способу сівби $-0,14$} \\
\hline
\end{tabular}


СІЛЬСЬКЕ ГОСПОДАРСТВО. РОСЛИННИЦТВО

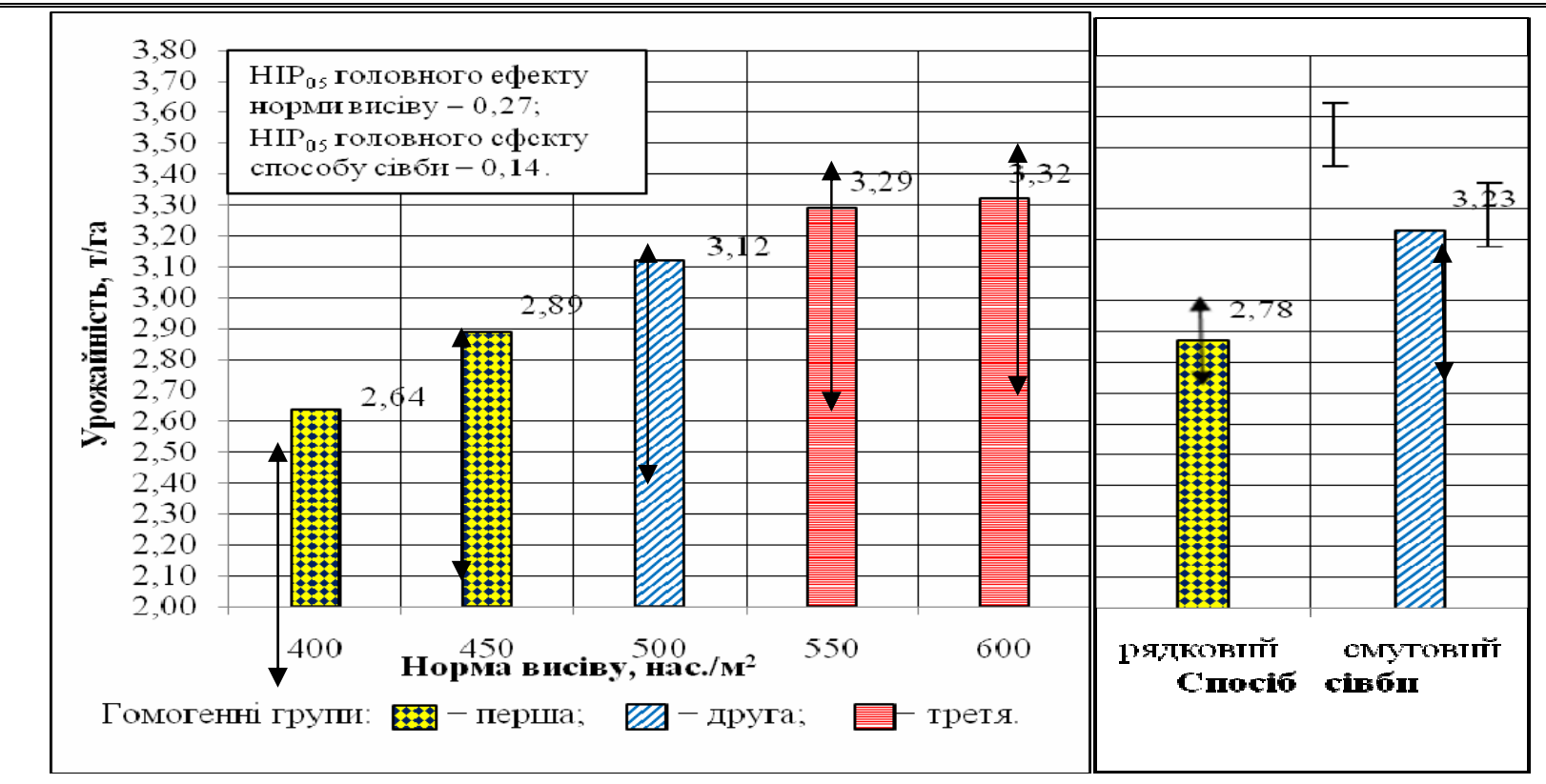

Рис. Урожайність зерна рослин тритикале ярого

за впливу різних норм висіву та способів сівби, m/2а (середнє за 2008-2010 рр.)

Розрахунки енергетичної ефективності вирощування тритикале ярого за різних варіантів норми висіву та способів сівби свідчать про високу ефективність цих агрозаходів (табл. 2). У середньому за три роки досліджень Кее вирощування тритикале ярого становив 4,68 - на ва- ріантах смугового способу сівби, тоді як на рядкових посівах - 4,16. Зростання Кее за умови застосування смугового способу сівби зумовлювалося вищим показником акумульованої енергії врожаєм за практично рівнозначних витрат енерriii.

\section{2. Біоенергетична ефективність вирощування тритикале ярого залежно} від застосування різних варіантів норм висіву та способів сівби (середнє за 2008-2010 рр.)

\begin{tabular}{|c|c|c|c|c|c|c|}
\hline \multirow{2}{*}{$\begin{array}{c}\text { Чинник А - } \\
\text { норма висіву, } \\
\text { нас./м² }\end{array}$} & \multirow{2}{*}{$\begin{array}{c}\text { Чинник В } \\
\text { - спосіб } \\
\text { сівби }\end{array}$} & \multirow{2}{*}{$\begin{array}{l}\text { Урожай- } \\
\text { ність, т/га }\end{array}$} & \multicolumn{2}{|c|}{$\begin{array}{c}\text { Затрати не поновлю- } \\
\text { ваної енергії, МДж }\end{array}$} & \multirow{2}{*}{$\begin{array}{c}\text { Акумульо- } \\
\text { вана енергія } \\
\text { врожаєм, } \\
\text { МДж/га }\end{array}$} & \multirow{2}{*}{$\begin{array}{c}\text { Коефіцієнт } \\
\text { енергетичної } \\
\text { ефективності } \\
\text { (Кее) }\end{array}$} \\
\hline & & & на 1 га & $\begin{array}{l}\text { на } 1 \mathrm{~T} \\
\text { зерна }\end{array}$ & & \\
\hline \multirow{2}{*}{400} & рядковий & 2,59 & 10654 & 4114 & 42994 & 4,04 \\
\hline & смуговий & 2,69 & 10674 & 3968 & 44654 & 4,18 \\
\hline \multirow{2}{*}{450} & рядковий & 2,78 & 11046 & 3973 & 46148 & 4,18 \\
\hline & смуговий & 3,00 & 11066 & 3689 & 49800 & 4,50 \\
\hline \multirow{2}{*}{500} & рядковий & 2,95 & 11438 & 3877 & 48970 & 4,28 \\
\hline & смуговий & 3,29 & 11458 & 3483 & 54614 & 4,77 \\
\hline \multirow{2}{*}{550} & рядковий & 3,01 & 11830 & 3930 & 49966 & 4,22 \\
\hline & смуговий & 3,56 & 11850 & 3329 & 59096 & 4,99 \\
\hline \multirow{2}{*}{600} & рядковий & 3,01 & 12230 & 4063 & 49966 & 4,09 \\
\hline & смуговий & 3,63 & 12250 & 3375 & 60258 & 4,92 \\
\hline \multirow{5}{*}{$\begin{array}{r}\text { Середнє за } \\
\text { чинником A }\end{array}$} & 400 & 2,64 & 10664 & 4041 & 43824 & 4,11 \\
\hline & 450 & 2,89 & 11056 & 3831 & 47974 & 4,34 \\
\hline & 500 & 3,12 & 11448 & 3680 & 51792 & 4,52 \\
\hline & 550 & 3,29 & 11840 & 3630 & 54614 & 4,61 \\
\hline & 600 & 3,32 & 12240 & 3719 & 55112 & 4,50 \\
\hline \multirow{2}{*}{$\begin{array}{c}\text { Середнє за } \\
\text { чинником В }\end{array}$} & рядковий & 2,87 & 11440 & 3991 & 47642 & 4,16 \\
\hline & смуговий & 3,23 & 11460 & 3569 & 53618 & 4,68 \\
\hline \multicolumn{2}{|c|}{ Середнє } & 3,05 & 11450 & 3780 & 50630 & 4,42 \\
\hline
\end{tabular}




\section{СІЛЬСЬКЕ ГОСПОДАРСТВО. РОСЛИННИЦТВО}

Найвищі показники біоенергетичної ефектив-

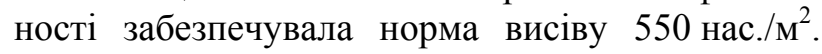
Зменшення норми висіву (як і іiі підвищення) приводило до зниження Кее; у першому випадку - через зниження акумульованої енергії врожаєм зерна, у другому - через значне підвищення витрат не поновлюваної енергії за незначного підвищення врожайності зерна. Ефект норми висіву залежав від характеру розподілу рослин за площею живлення. На варіантах рядкового способу сівби вищі біоенергетичні показники були за норми висіву 500 нас./ $\mathrm{m}^{2}$, тоді як на смугових посівах за норми висіву 550 нас./ $\mathrm{M}^{2}$.

В умовах лібералізації економічної діяльності ефективність сільськогосподарського виробництва значною мірою визначається конкурентоспроможністю продукції. Ефективне конкурентоспроможне виробництво суттєво залежить від вибору технології та оптимального управління технологічними процесами. Проведені розрахунки економічної ефективності вирощування тритикале ярого показали високу ефективність смугового способу, що полягала у значному збільшенні рівня рентабельності й прибутку порівняно $з$ контролем (табл. 3).

У середньому за нормами висіву, у разі застосування смугового способу сівби, приріст чистого прибутку, порівняно 3 контролем, становив
563 грн/га (33,2\%). Рівень рентабельності був вищий на $26 \%$. Значне підвищення економічної ефективності на варіантах смугового способу забезпечувалося значно вищою вартістю зерна 3 гектара за практично рівнозначних витрат на вирощування. Різниця між показниками економічної ефективності за досліджуваних способів сівби поступово підвищувалася зі збільшенням норми висіву насіння і найбільшою була за норми $600 \mathrm{нас.} / \mathrm{M}^{2}$. Так, якщо за норми висіву $400 \mathrm{Hac} . / \mathrm{M}^{2}$ приріст прибутку від застосування смугового способу порівняно з рядковим становив 190 грн/га, то за норми 600 нас. $/ \mathrm{M}^{2}-$ 918 грн/га.

3 точки зору економічної ефективності, кращим був варіант із проведенням сівби смуговим способом і нормою висіву 550 нас. $/ \mathrm{m}^{2}$. У цьому варіанті собівартість була найнижчою $(667$ грн/т), а рівень рентабельності найбільшим - $110 \%$. Зі збільшенням норми висіву до 600 нас./м² чистий прибуток зменшувався на 5 грн/га, тоді як собівартість зростала на 16 грн/т, а рентабельність зменшувалася зі 110 до $105 \%$.

Рядкова сівба, на відміну від смугової, кращі показники собівартості та рентабельності забезпечувала за норми висіву $500 \mathrm{нас.} / \mathrm{M}^{2}$. Підвищення норми висіву з 500 до 600 нас./м² різко зменшувало показники економічної ефективності.

\section{3. Економічна ефективність вирощування тритикале ярого залежно від впливу різних норм висіву та способів сівби (середнє за 2008-2010 рр.)}

\begin{tabular}{|c|c|c|c|c|c|c|c|c|}
\hline $\begin{array}{c}\text { Норма } \\
\text { висіву (А), } \\
\text { нас./м² }\end{array}$ & $\begin{array}{c}\text { Спосіб } \\
\text { сівби* } \\
\text { (В) }\end{array}$ & $\begin{array}{c}\text { Урожай- } \\
\text { ність, } \\
\text { т/га }\end{array}$ & $\begin{array}{c}\text { Вартість } \\
\text { зерна, ** } \\
\text { грн/га }\end{array}$ & $\begin{array}{c}\text { Витрати, } \\
\text { грн/га }\end{array}$ & $\begin{array}{c}\text { Прибуток, } \\
\text { грн/га }\end{array}$ & $\begin{array}{c}\text { Приріст } \\
\text { прибутку, } \\
\text { грн/га }\end{array}$ & $\begin{array}{c}\text { Собівар- } \\
\text { тість, } \\
\text { грн/га }\end{array}$ & $\begin{array}{c}\text { Рентабе- } \\
\text { льність, } \\
\text { \% }\end{array}$ \\
\hline \multirow{2}{*}{400} & 1 & 2,59 & 3626 & 2114 & 1512 & - & 816 & 72 \\
\hline & 2 & 2,69 & 3766 & 2064 & 1702 & 190 & 767 & 82 \\
\hline \multirow{2}{*}{450} & 1 & 2,78 & 3892 & 2219 & 1673 & 161 & 798 & 75 \\
\hline & 2 & 3,00 & 4200 & 2169 & 2031 & 519 & 723 & 94 \\
\hline \multirow{2}{*}{500} & 1 & 2,95 & 4130 & 2320 & 1810 & 298 & 786 & 78 \\
\hline & 2 & 3,29 & 4606 & 2270 & 2336 & 824 & 690 & 103 \\
\hline \multirow{2}{*}{550} & 1 & 3,01 & 4214 & 2425 & 1789 & 277 & 806 & 74 \\
\hline & 2 & 3,56 & 4984 & 2375 & 2609 & 1097 & 667 & 110 \\
\hline \multirow{2}{*}{600} & 1 & 3,01 & 4214 & 2528 & 1686 & 174 & 840 & 67 \\
\hline & 2 & 3,63 & 5082 & 2478 & 2604 & 1092 & 683 & 105 \\
\hline \multirow{5}{*}{$\begin{array}{c}\text { Середнє за } \\
\text { A }\end{array}$} & 400 & 2,64 & 3696 & 2089 & 1607 & - & 791 & 77 \\
\hline & 450 & 2,89 & 4046 & 2194 & 1852 & 245 & 759 & 84 \\
\hline & 500 & 3,12 & 4368 & 2295 & 2073 & 466 & 736 & 90 \\
\hline & 550 & 3,29 & 4599 & 2400 & 2199 & 592 & 729 & 92 \\
\hline & 600 & 3,32 & 4648 & 2503 & 2145 & 538 & 754 & 86 \\
\hline \multirow{2}{*}{$\begin{array}{c}\text { Середнє за } \\
\text { В }\end{array}$} & 1 & 2,87 & 4015 & 2321 & 1694 & - & 809 & 73 \\
\hline & 2 & 3,23 & 4528 & 2271 & 2257 & 563 & 703 & 99 \\
\hline \multicolumn{2}{|c|}{ Середнє } & 3,05 & 4271 & 2296 & 1975 & 767 & 753 & 86 \\
\hline
\end{tabular}




\section{СІЛЬСЬКЕ ГОСПОДАРСТВО. РОСЛИННИЦТВО}

Висновок. Рівень реалізації потенціалу продуктивності рослин тритикале ярого значною мірою обумовлювався нормою висіву та способом сівби. Оптимізація цих технологічних елементів забезпечувала підвищення врожайності рослин тритикале ярого за мінливих погодних умов років досліджень.

\section{БІБЛІОГРАФІЯ}

1. Биоэнергетическая оценка севооборотов: метод. рекомендации / РАСХН. Сиб. отделение. Сиб. НИИСХ. - Новосибирск, 1993. - 36 с.

2. Бозолова Е. И. Методика биоэнергетической оценки технологии производства продукции растениеводства / Е. И. Бозолова, Е. В. Глинка. М. : Колос, 1983. -45 c.

3. Горбачова О. Ю. Біоенергетична оцінка ресурсозберігаючої технології вирощування сільськогосподарських культур в умовах степової зони УРСР / О. Ю. Горбачова, М. В. Орешкін // Вісник с.-г. науки. - 1988. - № 9. - С. 28-33.

4. Доспехов Б. А. Методика полевого опыта / Б. А. Доспехов - М. : Агропромиздат, 1985. $351 \mathrm{c}$.

5. Коринеи В. В. Теоретические основы системно-энергетического подхода обработки почв / В. В. Коринец // Науч. тр. ВАСХНИЛ. - Курск, 1989. - C. 101-108.

6. Медведовський O. К. Енергетичний аналіз інтенсивних технологій в сільськогосподарському виробництві / О. К. Медведовський, П. І. Іваненко. - К. : Урожай, 1988. - 208 с.

7. Методические указания для подготовки и написания дипломних проектов (работ по экономической и энергетической оценке результа-
Найвища зернова продуктивність рослин формувалася на варіантах смугового способу за норми висіву 550 нас. $/ \mathrm{M}^{2}$.

Смугова сівба за оптимізації норми висіву забезпечувала також одержання вищих показників енергетичної та біоенергетичної ефективності вирощування посівів тритикале ярого.

тов исследований) / Сост. В. П. Мартьянов. - Х., 1996. $-30 \mathrm{c}$.

8. Овсянников Ю. И. Эколого-экономические аспекты применения средств химизации / Ю. И. Овсянников, М. П. Данько // АПК: достижения науки и техники. -1999 . - №8. - С. 12-14.

9. Терехов А.И. Экономические проблемы развития производства проса / А. И. Терехов // ВАСХНИЛ ВНИИ зернобобовых и крупяных культур. - Орел, 2001. - С. 3-7.

10. Томащівський 3. М. Продуктивність озимого жита залежно від обробітку грунту і удобрення в умовах Полісся України / 3. М. Томашівський, А. П. Білітюк, А. І. Макарук // Зб. наук. праць Інституту землеробства УААН. - К.: Нора-Прінт, 1999. - Вип. 3. - С. 3-8.

11. Тооминг $X$. Г. Экологические принципы максимальной продуктивности посевов / Х. Г. Тооминг. - Л. : Гидрометеоиздат, 1984. $264 \mathrm{c}$.

12. Фатыхов И. Ш. Озимая пшеница в адаптивном земледелии Среднего Предуралья: монография / И. Ш. Фатыхов, Л. А. Толканова, Н. Г. Туктарова; под ред. И. Ш. Фатыхова. - Ижевск: РИО ФГОУ ВПО «Ижевская ГСХА», 2005. $156 \mathrm{c}$. 